\title{
The Anatomy of Ingrid Mattson's Interpretation of the Qur'an: History, Authority, and Translation Problems
}

\author{
Ahmad Saefudin ${ }^{1}$, Ahmad Rafiq ${ }^{2}$, Marhumah $^{3}$ \\ ${ }^{1}$ Universitas Islam Nahdlatul Ulama Jepara, Indonesia \\ 1,2,3UIN Sunan Kalijaga Yogyakarta, Indonesia \\ 12ahmadsaefudin@unisnu.ac.id, 2ahmad.rafiq@uin-suka.ac.id, ${ }^{3}$ marhumah@uin-suka.ac.id
}

DOI: $10.29240 /$ alquds.v5i1.2300

Submitted: 2021-01-13 | Revised: 2021-03-09 | Accepted: 2021-03-31

\begin{abstract}
Many contemporary thinkers have introduced various theories in Quranic studies. For example, Fazlur Rahman with double movement theory, Gadamer through a fusion of the horizon, and Abdullah Saeed with contextual interpretation. Meanwhile, Ingrid Mattson's thoughts on the interpretation of the Koran have not been widely studied by scholars. Mattson has placed the historical context, the personal context of the reader, and the context of the reader's understanding as an integral part of the theory of interpretation. This article wishes to dissect the anatomy of Mattson's interpretation of the Koran. With the historical textual criticism approach popularized by Muhammad Mustafá Azami, this study concludes that apart from historical aspects, the interpretation of the Koran is also strongly influenced by the authority of the rulers at that time, individual charisma (ulama), and the consensus of religious experts. The reduction of God's message is also very vulnerable to the rampant action of translating the Koran from Arabic into ajam (non-Arabic) language. These three aspects are the constructs of Mattson's thought in his hermeneutical study. Therefore, it is hoped that this academic discourse will add to the style of thinking of scholars in the field of Qur'an studies, which previously have colored contemporary exegesis studies.
\end{abstract}

Keywords: Ingrid Mattson; interpretation of the Qur'an; contemporary exegesis; authority.

\section{Introduction}

The study of the Koran should accommodate two crucial aspects, namely text and context. If we ignore one of the two domains, the result will fall into a "hole" that is equally deep. Being too loyal to the text, by neglecting the context, has the potential to lead "The Interpreter" to a textual hole that is rigid, rigid, and stagnant. On the other hand, if we "deify" the context and run away from the vortex of the text, it provides opportunities for the seeds of interpretation which in Javanese terms is called kebablasen (extreme). In the realm of ulum al-Qur'an, 
textual interpretation is termed tafsir bi al-ma'tsur. ${ }^{1}$ Meanwhile, contextual interpretation is known as tafsir bi al-ra'yi. ${ }^{2}$ The polemic between the two schools of interpretation is indicated by some observers to have hampered productive integration in investigative efforts into the study of the Koran. ${ }^{3}$

Contemporary Koranic scholars make various theoretical claims of hermeneutics. Fazlur Rahman, for example, popularized the double movement theory in text dialectics, author, and reader. Gadamer introduced the concept of the fusion of horizon, ${ }^{4}$ namely trying to go beyond the original understanding to be integrated into a broader understanding to have a new perspective. ${ }^{5}$ Likewise, Abdullah Saeed introduced the methodology of contextual interpretation in his various works. ${ }^{6}$ Another theorist who has not had much thought in the study of the Koran is Ingrid Mattson, a scholar of Islamic studies, an expert in interfaith relations and a Muslim religious leader and professor of Islamic Studies at Hartford Seminary (Connecticut), who heads the Islamic Society of North America, one of the largest Muslim associations in the United States. ${ }^{7}$ His authoritative book entitled The Story of The Qur'an: Its History and Place in Muslim Life become a reference for observers of the study of the Koran in various parts of the world because it is considered to link the holy book of Muslims with context, stories, and historical aspects. ${ }^{8}$ On another occasion, Mattson also linked the Koran with women's and gender issues.

${ }^{1}$ The tools used by the interpreter in finding the meaning of certain verses in the Koran are the verses of the Koran itself and Al-Hadith. Hukmiah Hukmiah and Masri Saad, "Al-Qur'an antara Teks dan Konteks," Dirasat Islamiab: Jurnal Kajian Keislaman 1, no. 1 (2020): 4.

${ }^{2}$ Interpreters rely on the power of reason to find the true meaning of a verse in the Koran. Rendi Fitra Yana, Fauzi Ahmad Syawaluddin, and Taufiqurrahman Nur Siagian, "Tafsir Bil Ra'yi," Pena Cendikia 02, no. 01 (March 2020): 1-6.

${ }^{3}$ Richard C Martin, "Understanding the Qur'an in Text and Context," History of Religions 21, no. 4 (1984): 361.

${ }^{4}$ Hans-Georg Gadamer, Truth and Method, Second, Re (London and Newyork: Continuum Publishing Group, 2006), 305.

5 David Vessey, "Gadamer and the Fusion of Horizons," International Journal of Pbilosophical Studies 17, no. 4 (2009): 534, https://doi.org/10.1080/09672550903164459.

${ }^{6}$ Abdullah Saeed, Interpreting the Qur'an: Towards a Contemporary Approach (New York: Taylor \& Francis e-Library, 2006); Abdullah Saeed, Islamic Thought: An Introduction (New York: Taylor \& Francis e-Library, 2006), https://doi.org/10.4324/9780203088685; Abdullah Saeed, The Qur'an: An Introduction, The Qur'an (New York: Taylor \& Francis e-Library, 2008), https://doi.org/10.4324/9780203938454-12.

${ }^{7}$ Brian Knowlton, "Muslim Women Gain Higher Profile in US," 2010, 2-3.

${ }^{8}$ Ingrid Mattson, The Story of The Qur'an: Its History and Place in Muslim Life, John Wiley \& Sons, 2013, https://doi.org/10.5860/choice.46-0829. The Indonesian edition which the author will frequently quote in this paper can be seen in Ingrid Mattson, Ulumul Quran Zaman Kita: Pengantar Untuk. Memahami Konteks, Kisah, Dan Sejarah Al-Quran (Jakarta: Zaman, 2013).

${ }^{9}$ Ingrid Mattson, "Can a Woman Be an Imam? Debating Form and Function in Muslim Women's Leadership," The Columbia Sourcebook of Muslims in the United States, 2005, 252-63, 
Therefore, through qualitative research with a literature approach, this study aims to map the anatomy of Ingrid Mattson's thoughts in interpreting the Koran. As an analytical tool, the researcher borrows the historical criticism method popularized by Muhammad Mustafá Azami. ${ }^{10}$ A theoretical contribution, this paper is expected to complement and enrich the variety of thoughts of ulum al-Qur'an scholars who previously have colored many contemporary exegesis studies. On a practical level, this research can be used by future researchers to study the Koran not only from a historical point of view, as has been done by many observers above. But also pay attention to the domain of "authority" that influences the process of interpreting the Koran.

The study of the historical aspects of the Koran as a context of interpretation has been in great demand by scholars, such as Abdullah Saeed, Gabriel Said Reynolds, and Andrew Rippin. ${ }^{11}$ In line with Mattson, Abdullah Saeed made the Hijaz culture a starting point in his search for the meaning behind the text of the Koran. The actions, words, and consent of the Prophet Muhammad, which later became the source of authoritative law in Islam, cannot be separated from the cultural construction of the Hijaz as the locus. Therefore, the message of the Koran adjusts the point of view of the Hijaz community as the first recipient. Each text contains symbols, metaphors, terms, and expressions commonly applicable in the Hejaz. So, following Saaed's opinion, when the Koran introduced the concept of Heaven as a reward for the afterlife for believers, for example, he linked it to the local Hijaz culture and the popular imagination of Arab society, namely using the metaphor of fruit, trees, gardens, and flowing rivers. ${ }^{12}$ What Saeed did continued the tradition of criticism of the history of the text of the Koran that had been done by Arthur Jeffery. These English Orientalists relied on manuscript material from early 4th century Hijri scholars as primary references, such as Ibn Mas'ud, Ubai ibn Ka’b, Ibn Abbas,

http://thewomenofislam.tripod.com/womenimams.pdf; Ingrid Mattson, "Women, Islam and Mosques," Encyclopedia of Women and Religion in North America 615, no. 618 (2006).

${ }_{10}$ Muhammad Mustafa Azami, The History of the Quranic Text: From Revelation to Compilation: A Comparative Study with the Old and New Testaments, Second (Al-Qalam Publishing, 2011). Indonesian edition, see inside Muhammad Mustafa Azami, Sejarah Teks Alquran Dari Wabyu Sampai Kompilasi: Kajian Perbandingan Dengan Perjanjian Lama Dan Perjanjian Baru (Jakarta: Gema Insani, 2005). In his commentary, Azami asked three critical questions about the Koran. What is the essence of the Koran? If there is a difference between the current and ancient Quranic manuscripts, what will be the effect on the Quranic text today? Who is the authoritative figure of the writing of the Koran and its history? The three lenses will be used by researchers to answer the anatomy of Mattson's thoughts in interpreting the Koran.

${ }^{11}$ Andrew Rippin, Approaches to the History of the Interpretation of the Qur'an, ed. Andrew Rippin (Oxford: Clarendon Press, 1988), https://doi.org/10.2307/1596080.

${ }^{12}$ Saeed, The Qur'an: An Introduction, 12. 
Anas ibn Malik, to Ubaid ibn Umar. Then, they were supported by secondary manuscripts born from al-Aswad, 'Alqama, Hittan, Sa'id ibn Jubair to al-Harith ibn Suwaid. ${ }^{13}$ This effort further strengthens the theoretical claim that the text of the Koran is closely related to the historical aspects of its preachers. Such retrospective lenses are getting closer to the readers of the Koran to present historical contextual perspectives. ${ }^{14}$

In addition to the historical dimension, several scholars, who studied the Koran, used the authority approach as the basis for their analysis. They are such as Juliane Hammer, ${ }^{15}$ Johanna Pink,${ }^{16}$ and Khaled Abou El Fadl. ${ }^{17}$ Not a few of them intensively link the study of the Koran with the realm of translation. Example M.A.S. Abdel Haleem ${ }^{18}$ and Hayat Mohamed Osman Seid Ahmed. ${ }^{19}$

This research is a continuation of the efforts of the thinkers above in uncovering various problems of interpretation. Because, somewhat different from the results of previous research which seem to place the historical aspects, scientific authority, and the development of translation separately, this study would like to emphasize that these three aspects are integrally closely related. Mattson clearly states that three important contexts that need to be considered by readers of the Koran, both Muslims and non-Muslims, are: 1) Historical context. More precisely, when and where the Koran was revealed, interpreted, and read by the public for hundreds of years. 2) The personal context of the reader, including the scientific background, assumptions, and prejudices that have previously stuck

1937).

${ }^{13}$ Arthur Jeffery, "Materials for the History of the Text of the Qur'an” (Leiden: Brill,

${ }^{14}$ Gabriel Said Reynolds, New Perspectives on the Qur'än: The Qur'ann in Its Historical Context 2 (New York: Routledge, 2011).

15 Juliane Hammer, "Identity, Authority, and Activism: American Muslim Women Approach the Qur'an," The Muslim World 98, no. 4 (2008): 443-64.

${ }^{16}$ Johanna Pink, "Tradition, Authority and Innovation in Contemporary Sunnī Tafsīr: Towards a Typology of Qur'an Commentaries from the Arab World, Indonesia and Turkey,” Journal of Qur'anic Studies 12, no. 2010 (2010): 56-82, https://doi.org/10.3366/e1465359110000963; Johanna Pink, Muslim Qur'anic Interpretation Today: Media, Genealogies and Interpretive Communities (London: Advent Publishing Services, 2019). Johanna Pink's attention in studying the Koran has also spread to translation studies. Look inside Johanna Pink, "Literal Meaning'or 'Correct 'aqīda'? The Reflection of Theological Controversy in Indonesian Qur'an Translations," Journal of Qur'anic Studies 17, no. 3 (2015): 100-120, https://doi.org/10.3366/jqs.2015.0213.

${ }_{17}$ Khaled Abou El Fadl, Speaking in God's Name: Islamic Law, Authority, and Women (London: Oneworld Publications, 2014).

${ }^{18}$ M. A.S.Abdel Haleem, "The Role of Context in Interpreting and Translating the Qur'an,” Journal of Qur'anic Studies 20, no. 1 (2018): 47-66, https://doi.org/10.3366/jqs.2018.0320.

${ }^{19}$ Hayat Mohamed Osman Seid Ahmed, "A Study on the Difficulties of Translating the

Religious Text," International Journal of English and Education 9, no. 1 (2020): 183-200. 
in his mind. 3) The context of the reader's understanding of the esoteric meaning of the terms expressed. ${ }^{20}$

\section{Result and Discussion}

\section{Historical Context in Understanding the Koran}

The story of Khawlah bint Tsa'labah which triggers the zihar verse in the Koran, for Ingrid Mattson, is the central point of the importance of understanding God's revelation in the historical dimension. By placing the Koran as a unitary text that combines separate revelations due to reactions to human problems in its day, the historical domain becomes an aspect that readers should not ignore. Only through this, we can know the details of the Prophet Muhammad when receiving revelation from God. Also, we can carry out an in-depth study of the narrative of the Qur'an in describing itself in the form of revelations and other fundamental messages, both explicit and implicit, which God has prepared for mankind. ${ }^{21}$ As a Muslim, of course he believes that the Koran transcendently provides spiritual guidance to the Prophet Muhammad in resolving affairs with fellow Muslims, Muslim communities and others, and also be justification in defending and supporting religious actions and teachings. ${ }^{22}$

Among the contexts that must be analyzed by readers of the Koran is the situation of Mecca, in particular, and Arabic in general, which is closely related to its distinctive culture and language. Since the time of Prophet Ibrahim (as), Makkah has become a symbol of the teachings of monotheism, which is represented by the Ka'bah as bayt Allah (God's house). Islam is historically the successor to two previous Semitic religions, namely Judaism and Christianity. Arabic, before becoming the language of science in the $9^{\text {th }}$ to $12^{\text {th }}$ centuries $A D$, was used by the Babylonians, Chaldeans, Hittites, and Phoenicians, who at that time already had a great civilization. ${ }^{23}$

${ }^{20}$ Ingrid Mattson, "How to Read The Quran," in The Study Quran : A New Translation and Commentary, ed. Seyyed Hossein Nasr et al. (New York: HarperOne, 2015), 1587.

${ }^{21}$ Mattson, Ulumul Quran Zaman Kita: Pengantar Untuk. Memabami Konteks, Kisah, Dan Sejarah Al-Quran, 18.

${ }^{22}$ Hussam Almujalli, "The Relationship between the Prophet Muhammad and the Quran," Journal of Islamic Studies and Culture 2, no. 4 (2014): 1, https://doi.org/10.15640/jisc.v2n4a1.

${ }^{23}$ Philip K. Hitti, History of the Arabs (Macmillan International Higher Education, 2002). I use the Indonesian edition in Philip K. Hitti, History of The Arabs (Jakarta Selatan: Zaman, 2018), 6. For comparison, see also Albert Hourani, A History of the Arab Peoples, Updated ed (Faber \& Faber, 2013), 12, https://doi.org/10.1017/cbo9780511570780.005. 
The context of Makkah, especially in the story of the construction of the Ka'bah that was told by the Alquran in the QS. Al-Baqarah: 127, in Mattson's view, not only shows the sanctity of the place, but also an implicit indication that implies the flexibility of Islam to the local Arab tradition and also the statement of originality of monotheism was held by him.

He (Prophet Muhammad) showed that their noble ancestors, Abraham, Hajar, and Ismail, were not idol worshipers around the Ka'bah. Their ancestors worshiped God Almighty. So it is Islam, not idolatry, that is the original belief and the most authentic carrier of Arab tradition. ${ }^{24}$

Arabic is the next important context in Mattson's concern. Starting from the $7^{\text {th }}$ century, Arabic has been used as a medium for conveying ethnic values and identities and a distinctive component that distinguishes it from non-Arab circles. However, they tend to use it in the form of oral, not written communication. ${ }^{25}$ So it is not surprising that some observers define the Koran as an oral revelation in Arabic that was first heard by the Prophet Muhammad. and then written in an Arabic alphabet consisting of 114 chapters, more than 6.200 verses, and arranged according to a predetermined order. ${ }^{26}$ The ultimate of linguistic civilization at that time was symbolized by poetry which usually told about romance and warfare, group solidarity, clan loyalty, and criticism of opposing parties. To the extent that Hitti commented:

Not a single nation in the world has shown such appreciation for poetic nuanced expressions and has been deeply touched by words, both spoken and written, apart from the Arabs. It is difficult for us to find a language that can influence the minds of its users in such a profound way as Arabic. ${ }^{27}$

The best poets annually participate in the poetry festival on the Ukaz market. Poetry works that were considered the most phenomenal were then hung on the Kaaba (muaallaqat) as appreciation. In this literary phenomenon, Allah sent down the Koran to the Prophet Muhammad. For 'ajam (non-Arab) people like us

${ }^{24}$ Mattson, Ulumul Quran Zaman Kita: Pengantar Untuk. Memahami Konteks, Kisah, Dan Sejarah Al-Quran, 22-23.

${ }^{25}$ Mattson, 18. Based on Hitti's commentary, the earliest writings were only discovered in the 8th and 9th centuries $\mathrm{AD}$ in the form of epigraphs (writing on metal or stone). Its contents can be classified into five types, including 1) oaths, 2) architectural, 3) historical, 4) rules of order, and 5) obituaries. Philip K. Hitti, History of The Arabs (Jakarta: Zaman, 2018), 63.

${ }^{26}$ Seyyed Hossein Nasr et al., The Study Quran: A New Translation with Notes and Commentary (New York: HarperCollins Publishers, 2015).

${ }^{27}$ Hitti, History of The Arabs, 2018, 112. 
who grew up outside the Arab environment, it is necessary to master the i'rab to understand the Koran and poetry, which is full of metaphoric content. ${ }^{28}$

The next context that we must understand in reading the Koran according to Mattson is the terminology of jabiliyah. This term is described as a word that implies injustice, moral depravity, and ignorance. ${ }^{29}$ Philip K. Hitti, the author of History of The Arabs - that is considered the most authoritative main reference for the history of Islamic civilization - associates the term jabiliyah or the age of ignorance with the absence of three fundamental elements, namely the authority of law, prophets and holy books. It has been frequently mentioned by many historians that Arab societies, especially South Arabs, are not intellectually stupid. They are cultured and familiar with reading and writing. Even, the Arab Jabiliyah period that was pinned to the North Arabs, for Hitti, was not based on credible data because it only relied on history, legends, and poetry that reached the $2^{\text {nd }}$ and $3^{\text {rd }}$ century AH which were not recorded in the form of writing.

They are called jabiliyyah, one of which is caused by the phenomenon of ayyam al-A'rab, namely the "days of the Arabs" which were shrouded in hostility between tribes due to seizure of livestock, pasture disputes, or control of spring land. In the end, robbery and assault became common institutional traits in their lives. Even before he became a prophet, Muhammad was powerless not to be involved in warfare, for example, in the al-Fijjar War which involved the Quraish tribe and its allies, al-Kinanah against the Hawarin tribe. ${ }^{30}$

The loss of legal authority in the era of conquest forced the defeated tribes to submit to the will of the victorious tribe. On the other hand, the Prophet who was expected to bring God's law on earth was never present. The existence of the holy book as a guide for the life of the Arab community at that time had been denied. So, it is only natural that they are trapped in the mud of ignorance.

\section{Authority of Interpretation of the Qur'an: From Rulers, Individual Charisma, to the Consensus of Majority Ulama}

In Sunni culture, Islam does not recognize religious institutions that have the right to represent God's authority - through His Kalam - on earth. Perhaps, we know a group of scholars who interpret the Qur'an whose lives are spent trying to find the "Will of God", whose legal fatwas are followed by many communities, and their progressive thoughts have never been refuted. However again, there is

\footnotetext{
${ }^{28}$ Tahraoui Ramdane and Merah Souad, "Towards a New Approach in the Teaching of the Holy Qur'an,” International Journal of Humanities and Social Science 7, no. 10 (2017): 149.

${ }^{29}$ Mattson, Ulumul Quran Zaman Kita: Pengantar Untuk. Memahami Konteks, Kisah, Dan Sejarah Al-Quran, 31.

${ }^{30}$ Hitti, History of The Arabs, 2018, 109-11.
} 
no single interpreter, which has the authority to claim the truth of the results of its interpretation exclusively. ${ }^{31}$ However, this does not mean that the truth of the Koran is relative. As Muslims, of course, we believe that the Koran is a sacred holy book, and there is no doubt in it. However, when it has entered the interpretation area, "the truth of the interpretation of the Koran" is no longer absolute. Typically theories in other disciplines, the theory of interpretation of the Koran are also in the realm of fallibilism. ${ }^{32}$

Therefore, Mattson insists that since the death of the Prophet Muhammad, Muslims have been faced with serious problems regarding "who has the authority to define the desired meaning of the Qur'an."33 Although, in the end, this authority was played by the role of the caliph (successor to the leadership of the Prophet Muhammad), none of those has the privilege of being the sole interpreter of the Koran. Even, they rely on the knowledge of other friends who are more capable (understanding asbabun nuzul, the meaning of words, and mutasyabihat verses).$^{34}$ For example, a friend of Abdullah ibn al-Abbas, who was known by the public at that time as ablu al-Qur'an with his recitation classes. ${ }^{35}$

At the beginning of the period of interpreting the Koran, the efforts of the Muslim community to explain the meaning of the Koran did not require rigid hermeneutic rules like now. The new formal interpretation methodology emerged in subsequent development when the offers of interpretation from one interpreter were challenged by another group of interpreters. Even, the most dominant style of interpretation is not necessarily claimed to be the most correct and consistent

${ }^{31}$ Fadl, Speaking in God's Name: Islamic Law, Authority, and Women, 34.

${ }^{32}$ In simple terms, we can interpret fallibilism as an epistemological thesis that there is no absolute belief about theories, views, and etc. that can be rationally supported or conclusively justified. This is because there is always the possibility of doubt about the correctness of these beliefs. The opposite is infallibilism, which is the belief that scientific laws cannot change. Jessica Brown, Fallibilism: Evidence and Knowledge (New York: Oxford University Press, 2018).

${ }^{33}$ Mattson, Ulumul Quran Zaman Kita: Pengantar Untuk Memabami Konteks, Kisah, Dan Sejarah Al-Quran, 255-56.

${ }^{34}$ Mattson, 257.

35 It seems that Mattson is following the narrative of At-Tabari in Jami 'al-Bayan who narrates: "I saw Mujahid with a board when he asked Ibn 'Abbas about tafsir. Ibn 'Abbas told him:' Write! 'It seems that this continued until the explanation of the entire Qur'an was asked and written." From this hadith, it was later believed that Ibn 'Abbas had a book of commentaries. However, from the editors of this hadith, nothing shows explicitly that Ibn 'Abbas has a written interpretation. Although, Firuzabadi, a lexicographer known for his work in the form of a comprehensive Arabic dictionary entitled Al-Qamus al-Mubith wa al-Qabus al-Wasith, compiled a book entitled Tafsir Tanwir al-Maqayas min Tafsir Ibn 'Abbas. Besides Ibn 'Abbas, there are the names of the companions of the Prophet who represented early authoritative commentators, including Said Ibn Jubayr, Mujahid Ibn Jabbar, Farra Nahwa,' Akramah, and Ibn Jarih. For details, see the description Husayn 'Alawl Mehr, An Introduction to the History of Tafslr and Commentators of the Qur'an, Translator: Hamid Hussein Waqar (Qum: Al-Mustafa International Publication and Translation Center, 2012), 23-25. 
form of interpretation. The phenomenon that occurs is that various forms of popular interpretation are actually influenced by political power, individual interpreters' charisma, economic crisis, social tension, and emotional appeal. ${ }^{36}$

We can look at one case of interpretation in the final part of verse 34 of Surah At-Taubah, for example, which reads:

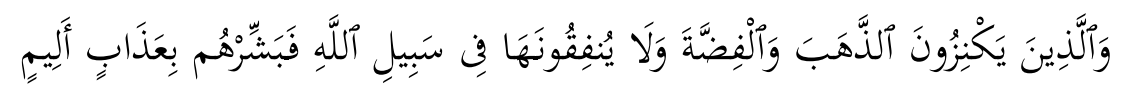

Meaning: "And those who keep gold and silver and do not spend it in the way of Allah, then tell them, (that they will get) a painful torment." (Surah At-Taubab: 34).

According to Hitti, as quoted by Mattson, the polemic of the interpretation of the above verse came from a friend of the Prophet Muhammad, Abu Dzarr, the governor of Syria, Muawiyah. Abu Dzarr used this verse to oppose the luxurious lifestyle practiced by Muawiyah. For him, the ascetic lifestyle must be carried out by Muslims, including a leader, as taught by the Prophet. However, Muawiyah rejected Abu Dzarr's interpretation by proposing a different perspective. According to Muawiyah, the ascetic practice contained in the verse is only intended for certain groups mentioned at the beginning of the verse, namely Christian priests and Jewish rabbis. Because the verse above reads completely:

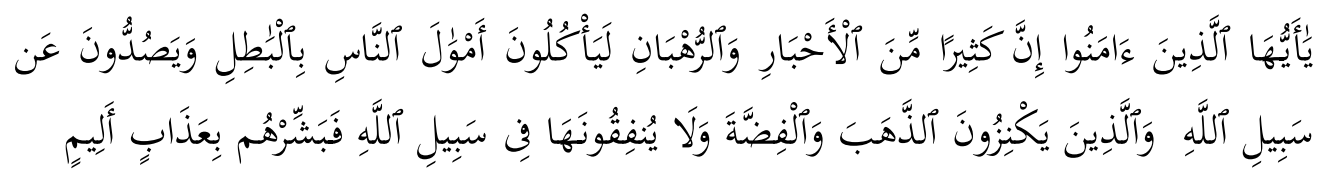

Although the verses are interpreted textually the same, the understanding between Abu Dzarr and Muawiyah in the context of the verse is different. Thus, in the methodology of interpretation, two interesting discussion points emerge about the extent to which the meaning of the verses of the Koran is limited to the series of verses or surah in which the verse is found and the extent to which the scope of the verse in question is applied. ${ }^{38}$ Apart from that, the charismatic figure Abi Dzarr as an ascetic preacher and Muawiyah figure who was then politically in power also influenced the style of interpretation of the Koran among Muslims in his time. Both of them get a lot of followers. The climax of the debate

\footnotetext{
${ }^{36}$ Mattson, Ulumul Quran Zaman Kita: Pengantar Untuk Memahami Konteks, Kisah, Dan Sejarah Al-Quran, 257-58.

37 "Quran Surat At-Taubah Ayat 34," 2020, https://tafsirweb.com/3050-quran-surat-attaubah-ayat-34.html.

${ }^{38}$ Mattson, Ulumul Quran Zaman Kita: Pengantar Untuk Memahami Konteks, Kisah, Dan Sejarah Al-Quran, 259.
} 
over the interpretation of the meaning of the Qur'anic verse, which is closely related to the political interests of power that occurred during the tabkim incident ${ }^{39}$ traveled by two camps; between the Caliph Ali ibn Abi Talib and the Muawiyah ibn Abi Sofyan group. Starting from this political event, finally, Muslims are held hostage by the longstanding theological contradictions to this day. ${ }^{40}$

The next problem, we are also faced with an epistemological challenge: how can a Muslim feel sure that he has understood the true meaning of the Koran without involving personal motives? Meanwhile, experts say that the best interpreter of the Koran is the Koran itself. However, as Ali ibn Abi Talib argued when debating with the Khawarij, it was not the Koran that interpreted it, but the people. Therefore, the Koran needs to be interpreted by relying on aspects of intellectuality and spirituality. The first aspect includes vocabulary, its implications, and significance in the original language (Arabic), which is exoteric in nature. Meanwhile, the second domain is associated with the spiritual struggle pursued by the Sufis, namely people who are spiritually elected through training (riyadlah) to understand the esoteric meaning of the Koran.

Until now, the discipline of interpretation is filled with various genres, such as the study of vocabulary, grammatical rhetoric, asbab an-nurul, stories of the prophets, the content of the law, scientific signs, and the disguised Qur'anic meanings. Also, various approaches are presented, for example, Muktazilah rationalism, Sufistic interpretation, philosophy, science, astrology, and so on. ${ }^{41}$ Hermeneutic tools such as root word tracing, grammatical structure analysis, and comparison of vocabulary usage patterns between verses are absolutely necessary for the interpreter to pursue relevant meaning content. The verse of the Koran is

39 This incident began with an open war between Ali ibn Abi Talib's troops, amounting to 50.000 people, and the Syrian army under the command of Muawaiyah ibn Abi Sofyan on the open plain of Shiffin, the west bank of the Euphrates river on July 28, 657 AD. Malik al-Asytar had to be put off by the ploy of 'Amr ibn 'Ash from the Muawiyah camp. Affixing a copy of the Koran on the spearhead marks the end of physical warfare and must be completed by following the decrees of the Koran (tabkim). The delegation of each camp conferred. Ali's side was represented by Abu Musa al-Asy'ari, who according to Hitti was described as a well-known pious figure, but his loyalty to Ali was still in doubt. In the meantime, Muawiyah submitted the case to 'Amr ibn' Ash, a longtime Arab politician. In the presence of 400 witnesses, the two arbitrators (bakam) held an open meeting in January 659 AD at Adhruh, a place between Medina and Damascus. Based on the descriptions of various popular histories, the two arbitrators agreed to dismiss their two leaders, Ali and Muawiyah. However, 'Amr ibn 'Ash successfully beat Abu Musa al-Asy'ari and succeeded in establishing Muawiyah as the new leader who replaced Ali ibn Abi Talib. Another history states that the two arbitrators both fired their respective leaders. It is just because Muawiyah at that time was governor and could sit on par with Caliph Ali in the negotiations, Muawiyah's leadership authority then soared. Hitti, History of The Arabs, 2018, 225 29.

${ }^{40}$ Harun Nasution, Teologi Islam (Jakarta: UI-Press, 2015), 3.

${ }^{41}$ Mattson, Ulumul Quran Zaman Kita: Pengantar Untuk. Memahami Konteks, Kisab, Dan Sejarah Al-Quran, 270-72. 
imperative in tone (command). In certain contexts, it means obligation, and in other contexts, it is only a suggestion. Without including various other factors outside the text, the interpreter cannot distinguish the meaning of these imperative verses.

The standard of interpretation, which was dominated by the ruling authority, in the next phase shifted to the hands of the scholars. They are considered authorized to formalize interpretation in anticipation of excessive glorification of reason. However, at the same time, intuition and common sense continue to work to maintain the authenticity of the meaning of the Koran, regardless of the various patterns that adorn it; Muktazilah with reason, Shia with the spiritual doctrine of their priests, and Sunnis with their sunnah and ijma'.

The importance of linking the context of the Koran, both with the sunnah, hadith, and asbabun nuzul, aims to explain verses that are still general and disguised in nature. Prayer orders, ablution procedures, and technical rituals of Sa'i between the Shafa-Marwa hills during the haj pilgrimage are concrete examples of the relevance of this contextualization process. The Koran does not specify the mechanism of worship above, so it needs an explanation of the results of the ulama's ijtihad. Consider the following Ingrid Mattson analysis:

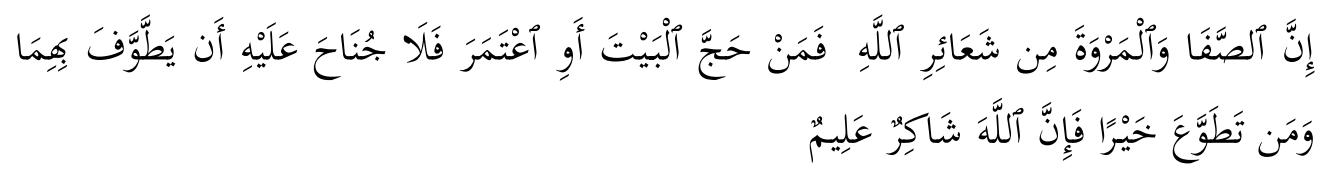

"Surely Shafaa and Marwa are part of the syi'ar of Allah. So whoever makes the pilgrimage to Baitullah or performs' umrah, then there is no sin for him to do sa'i between the two. And whoever does a good deed with a willing heart, then verily Allah is most grateful for goodness, is all-knowing. "\$2

Some of the Prophet's companions at that time thought that the ritual of sai (jogging between Shafa-Marwa) was not part of the pillars of Hajj because it represented a pre-Islamic ritual. However, Aisyah immediately clarified this assessment by explaining the context of her revelation (asbabun nuгul). The above verse wants to emphasize that sai is a ritual performed by the Prophet and at the same time wants to remove the stigma attached to sai rituals in the pre-Islamic period. Thus, it becomes clear the difference between sunnah and asbabun nuzul in explaining a verse. In this case, the sunnah shows the way the Prophet practiced the commands of the Koran. Meanwhile, asbabun nuгul looks at the context for a verse of the Koran, when revealed, may or may not be accompanied by relevant

42 “Quran Surat Al-Baqarah Ayat 158,” 2020, https://tafsirweb.com/630-quran-suratal-baqarah-ayat-158.html. 
information. Through asbabun nuzul, readers of the Koran will be saved from the traps of literal verses that may often be misunderstood.

As a result, I will close the paper's response to Ingrid Mattson's work by borrowing Khaled Abou El Fadl's expression in Speaking in God's Name: Islamic Law, Authority, and Women. He stated that submission to God is the essence of the Islamic faith. However, that does not mean blind submission to groups who like to claim to represent God's law. Submission to God means a willingness to act to involve the intellectual realm in pursuing God. Of course, this is accompanied by an attitude of humility. Because, in essence, there are no certain intellectuals or authoritative figures who can fully represent God. ${ }^{43}$

\section{Codification of the Koran and Translation Problems}

The search for the sanad or transmission chain of the qira'ab of the Koran as is done by Reem Osman in Ulumul Quran Zaman Kita: Pengantar Untuk. Memahami Konteks, Kisah, Dan Sejarah Al-Quran, for Ingrid Mattson, it has a crucial function of tracing the validity of sources; whether the type of reading the Koran someone relies on and continues to the Prophet Muhammad. or not. ${ }^{44}$ This is because the historical landscape of the claim to the authenticity of the word of God contains complex stories, starting from the memorization phase of the companions, taught orally in the form of reading (recited), to the stage of writing in the official corpus (written).

In the initial phase, the preservation of the Koran relies on the memory of the Prophet Muhammad and his friends. Arabs at that time were known to have a strong rote tradition. ${ }^{45}$ Then proceed to the next stage in the form of recording in written form. However, observers still categorize this phase as memorization. ${ }^{46}$ After the death of the Prophet and the death of many companions in the war of Yamamah, only did the consciousness of the Muslim elite emerge to codify the Qur'an in writing. Some observers believe that the effort to write the Koran in the form of a Mushaf has started since the first year after the death of the Prophet. To be precise, it was during the caliphate of Abu Bakr as-Sidiq on the proposal of Umar Ibn Khattab. Then, it was carried on massively during the caliph Uthman ibn Affan. This opinion is most popular among the theorists of Quranic studies. Technically, the friend Zaid ibn Thabit, who was appointed as the writing coordinator, compiled the Qur'anic text from animal skins, bone fragments, and notes from the companions who had heard directly

${ }^{43}$ Fadl, Speaking in God's Name: Islamic Law, Authority, and Women, 538.

${ }^{44}$ Mattson, The Story of The Qur'an: Its History and Place in Muslim Life, 79-85.

45 Aris Muzhiat, "Historiografi Arab Pra Islam," Tsaqôfah: Jurnal Agama Dan Budaya 17, no. 2 (2019): 132.

${ }^{46}$ Taufik Adnan Amal, Rekonstruksi Sejarah Al-Quran (Jakarta: Yayasan Abad Demokrasi, 2011), 155. 
from the Prophet. Two witnesses need validation to ensure the accuracy of these records before they are compiled into a subuf..$^{47}$ However, we also do not deny the records of some uncommon narrations which confirm that Ali ibn Abi Talib and Salim ibn Ma'qil were the first collectors of the Koran. ${ }^{48}$

One of the reasons for the codification of the Koran in the Mushaf was the emergence of polemics among Muslims regarding various readings that were considered correct according to what the Prophet taught. Thus, Hudzaifah ibn alYaman, a commander of troops in the border region of Armenia and Azerbaijan proposed to the Caliph Uthman ibn Affan, "unite the people before they argue with each other about the Bible such as the arguments of Jews and Christians." ${ }^{49}$

Seeing this motive, of course, Utsman ibn Affan made an effort to uniform the Koran reading at that time. This is because the orientation is to avoid internal feuds among the qurra' wal buffad\%. In response to Hudzaifah's request, Uthman sent a letter to Hafsah ${ }^{50}$ which reads "send us the subuf so we can make a perfect script and then I will return the temperature to you." ${ }^{51}$ Because of Uthman's courage to homogenize the dialect and reading of the Koran in certain domains ${ }^{52}$ such dialect and reading of the Koran only refer to one route, namely the Quraish tribe, which later raises debate in the eyes of some observers. This

${ }^{47}$ Mattson, Ulumul Quran Zaman Kita: Pengantar Untuk. Memahami Konteks, Kisah, Dan Sejarah Al-Quran, 142-43. In Taufik Adnan Amal's search, the Qur'an collection instrument used by Zaid ibn Tsabit includes six forms. 1) riqa ar or papyrus or parchment sheets; 2) likhäa or white slate, made of pieces of limestone which split horizontally due to heat; 3) 'asib or date palm midrib, made from the tip of the palm tree branch; 4) aktãf or shoulder blade, usually made of camel's shoulder blades; 5) adllă or ribs, usually also of camel ribs; and 6) adim or leather sheet, made of real animal skin, not parchment. Amal, Rekonstruksi Sejarah Al-Quran, 176-77.

48 Amal, Rekonstruksi Sejarah Al-Quran, 166.

${ }^{49}$ Mattson, Ulumul Quran Zaman Kita: Pengantar Untuk. Memahami Konteks, Kisah, Dan Sejarah Al-Quran, 44.

${ }^{50}$ Hafsah was the daughter of Umar ibn Khattab, also the wife of the Prophet Muhammad, who kept the codification of the Koran in the form of a letter from the bookkeeping project of the caliph Abu Bakr. Mattson, The Story of The Qur'an: Its History and Place in Muslim Life, 95. Zaid bin Thabit who was given the mandate to copy the manuscripts during the time of Uthman ibn Affan used the Subuf kept by Hafsah. The reason is, the temperature is considered the most standard. Zen Amrullah, Muhammad Hifdil Islam, and Mohammad Idris bin Ishak, "Kodifikasi Wahyu (Menyoal Kesejarahan Pembukuan Naskah Al-Qur'an)," Humanistika 6, no. 2 (2020): 225.

${ }^{51}$ Ulil Hidayah, "Kontroversi Mushaf Utsmani," ULUL ALBAB Jurnal Studi Islam 15, no. 1 (2014): 48, https://doi.org/10.18860/ua.v14i3.2661.

${ }^{52}$ Not all variations of the reading in the Utsmani Mushaf are omitted. If indeed the reading variation is believed to have been approved by the Prophet, then it is still said to be authentic so that it is accommodated in the Usmani mushaf. Mattson, Ulumul Quran Zaman Kita: Pengantar Untuk. Memahami Konteks, Kisah, Dan Sejarah Al-Quran, 145. 
choice is not without reason. As told by Jalaluddin As-Suyuthi in Al-Itqan fi Ulum al-Quran: ${ }^{53}$

Uthman said to three writers who came from Quraish, "If you (three of you) disagree with Zaid bin Thabit in the matter of writing the Qur'an, write it down in Quraish, because the Qur'an was sent down (by Allah SWT). in their language." They also carried it out so that when they had finished writing the original manuscripts in several manuscripts, Uthman returned the mushaf to Hafshah, then sent to each area one mushaf, and ordered all friends who had notes or other mushaf to be burned. ${ }^{54}$

The accusation that several revelations were not recorded in written form in the Uthmani Mushaf was because the deliberate element of the collectors came from the Shi'a sect. As the following explanation:

The Shi'i sect alleges that Uthman has replaced and did not include in his codification a large number of parts of the Koran, both in the form of letters, verses, and even certain words. The term usually used to express these various accusations is tabdîl or tabrif. If there is a view among other Islamic sects that parts of the Koran that are questionable for their authenticity are included in the Usmani mushaf because of the accidental or negligence of the collectors of the Koran, certain Shiite circles see them as tendentious and reflect intentions of evil collector. ${ }^{55}$

According to the author, the view of the Shia sect is a continuation of the long conflict between Ali bin Abi Talib's camp and Usman, which culminated in the Shiffin war. Since the "defeat" of Ali bin Abi Talib's camp, political issues have often spilled over into the theological realm. Not only in the context of the authenticity of the Koran, but the Shia sect also chooses its historical path in selecting the authenticity of a hadith of the Prophet. The perspective of Shia Imamiyah, for example, valid hadiths must include five conditions, including 1) Sincerity is continued to the Prophet. or the ma'shum Shia imams; 2) All the narrators came from the Shi'a Imamiyah group at each level; 3) All narrators are fair; 4) All transmitters are dhabit, and 5) Avoiding awkwardness (syudzûd»). The first requirement, in the view of Sunni scholars, is very exclusive. Because it only

2008).

${ }^{53}$ Jalal ad-Din As-Suyuthi, “Al-Itqan Fi 'Ulum Al-Qur'an” (Beirut: Resalah Publisher,

${ }^{54}$ I uses the Indonesian edition Jalaluddin As-Suyuthi, Studi Al-Qur'an Komprehensif, Jilid 1 (Surakarta: Indiva Pustaka, 2008), 250.

55 Amal, Rekonstruksi Sejarah Al-Quran, 271. 
relies on sanad on Shia imams. All the companions of the Prophet, for the Sunnis, could be accepted as narration as long as they met the five criteria above. ${ }^{56}$

Another controversy over the Uthmani Mushaf lies in the standardization of the order of the letters in the Koran. Starting with the longest letter, ending with the shortest letter. That is the order in general. All scholars agree that only the Prophet Muhammad has the right to place the order of verses and letters in the Koran through the guidance of Allah (tauqifi).$^{57}$ More than that, to fulfill the Qur'an standardization project, Uthman did not hesitate to instruct the destruction of copies of the Koran that were different from the Utsmani Mushaf. ${ }^{58}$ This is the root of the problem. Moreover, some friends still kept copies of the text of the Koran before Uthman worked on the codification of the holy book. ${ }^{59}$ Therefore, we should not just ignore the historical events of book-keeping the Koran into a single, long, and complicated manuscript.

In the next section, Ingrid Mattson focuses on the process of translating the Koran from Arabic into languages other than Arabic, including Indonesian of course. The Koran in the context of the essence of revelation is symbolized by Arabic. As a reminder that we should not be separated from the context of language, Mattson stated:

Translating the Koran into another language means ignoring the very strong spoken (sound) aspects of the interweaving rhyme sentences, the ending sound, and the poetic aspects of harmonious Arabic words. More importantly, it is impossible to apply the rules of tajwid into the translation 2 (2014): 151.

56 Muhammad Nasir, "Kriteria Keshahihan Hadis Perspektif Syiah," Jurnal Farabi 11, no.

${ }^{57}$ Ibn Faris said, "Jam'ul Qur'an" (codification of Al-Qur'an) is of two kinds. First, compiling the letters, such as prioritizing as-Sab'u ath-Thiwaal (the seven longest surahs), then accompanying them with al-Miain. Things like this were done by friends. As for the second one is compiling the verses in the Surahs of the Koran. This is tanqifi and this is what the Holy Prophet did, as obtained from Jibril, and Jibril from Allah." As-Suyuthi, Studi Al-Qur'an Komprehensif, Jilid 1,253. As-Suyuthi continued, "among the arguments that show that the order of the letters of the Qur'an is the ijtihad of the friends is the difference in the Companions' Mushaf in the order of their letters because some of them arrange the order of their letters. based on tartibun nuгul (descending order), such as Mushaf Ali, which begins with the letter Iqra' then al-Muddatstsir then Numn then al-Murzammil then Tabbat and then at-Takwir. That was until the end of al-Makki and al-Madani. As-Suyuthi, 258-59.

${ }^{58}$ Mattson, Ulumul Quran Zaman Kita: Pengantar Untuk Memahami Konteks, Kisah, Dan Sejarah Al-Quran, 146.

${ }^{59}$ Mattson, 147. 
of the Al-Qur'an ... Koran itself affirms in several of its verses that it is "the Arabic-speaking Koran.". ${ }^{0}$

The ontological status of the Koran as "the word of God" or "God's speech" is also debated by observers in the next development. This was what triggered the controversial mibnab (policy of examining the scholars) during the time of the Caliph Al-Makmun of the Abbasid dynasty in the early third century. Besides, also for political reasons that carry religious appendages. Many scholars have given up and are forced to admit that the Koran is a creature according to the Muktazilah doctrine. Only a few can survive. Among the few is Ahmad ibn Hanbal, a charismatic hadith expert from Baghdad. When questioned by Ishaq about his opinion on the Koran, Ahmad ibn Hanbal only answered briefly, "He is the word of Allah." Although provoked by additional questions, "was he created?" Ahmad ibn Hambal remains firm in his stance that the Koran is the word of God. As a hadith expert, he did not want to be trapped in the idea that Muktazilah was too deifying of reason. So it is not surprising when asked about the meaning of "All-hearing and All-Seeing", he firmly replied, "The form of God is as He described it." The phenomenon of mihnah becomes the gateway to another understanding which later gets the sympathy of many followers, namely the understanding of ahlusunnah wal jamaah, which was popularized by Abu Hasan Al-Asy'ari. For the Ashariyah people, the Koran is eternal (qadim), not created (makbluq). With a very beautiful analogy, Imam Al-Haramayn Al-Juwayni described, 'The writing of the Al-Qur'an, which is then read, is the result of the hand movements of the person who wrote it or the creation of a machine. All of that is only a temporary fabrication. The eternal Word of God is contained in those lines of writing." 61

That is a bit of the polemic that shrouds the history of the codification of the Koran and the problem of translating from Arabic into the traditional language. What is explained by Ingrid Mattson is increasingly convincing us that understanding the Koran requires a historical-anthropological approach? Not just fixated on normative texts.

\section{Conclusion}

Ingrid Mattson's anatomy of thought in his attempt to interpret the Koran can be classified into three types. First, Mattson believes that the activity of "capturing" God's message through His words must pay attention to the historical context, besides of course not neglecting the text. Second, the element of authority also needs attention. Especially the influence of the ruling minority, the individual charisma of a person, and the agreement of the scholars when the

\footnotetext{
${ }^{60}$ Mattson, 203-4.
}

${ }^{61}$ Mattson, 212. 
Qur'anic text is interpreted. Third, the codification of the Koran into a single manuscript and the rampant translation of Arabic into non-Arabic languages must be accompanied by contextual knowledge so that the authenticity of the text and meaning of the Koran is not reduced. It needs to be emphasized once again here, it does not mean that the Koran loses its sacred values. After all, the Koran implies God's message which is empirical, cosmological, and teleological.

In the future, scholars of the Qur'an should take advantage of Mattson's ideas as a basis in studying the Koran from its various aspects. Of course, by comparing the thinking models of other experts who are already familiar with contemporary commentators.

\section{Bibliography}

Ahmed, Hayat Mohamed Osman Seid. "A Study on the Difficulties of Translating the Religious Text." International Journal of English and Education 9, no. 1 (2020): 183-200.

Almujalli, Hussam. "The Relationship between the Prophet Muhammad and the Quran." Journal of Islamic Studies and Culture 2, no. 4 (2014): 1-5. https://doi.org/10.15640/jisc.v2n4a1.

Amal, Taufik Adnan. Rekonstruksi Sejarah Al-Quran. Jakarta: Yayasan Abad Demokrasi, 2011.

Amrullah, Zen, Muhammad Hifdil Islam, and Mohammad Idris bin Ishak. "Kodifikasi Wahyu (Menyoal Kesejarahan Pembukuan Naskah Al-Qur'an)." Humanistika 6, no. 2 (2020): 210-30.

As-Suyuthi, Jalal ad-Din. "Al-Itqan Fi 'Ulum Al-Qur'an.” Beirut: Resalah Publisher, 2008.

As-Suyuthi, Jalaluddin. Studi Al-Qur'an Komprehensif, Jilid 1. Surakarta: Indiva Pustaka, 2008.

Azami, Muhammad Mustafa. Sejarah Teks Alquran Dari Wabyu Sampai Kompilasi: Kajian Perbandingan Dengan Perjanjian Lama Dan Perjanjian Baru. Jakarta: Gema Insani, 2005.

. The History of the Quranic Text: From Revelation to Compilation: A Comparative Study with the Old and New Testaments. Second. Al-Qalam Publishing, 2011.

Fadl, Khaled Abou El. Speaking in God's Name: Islamic Law, Authority, and Women. London: Oneworld Publications, 2014.

Gadamer, Hans-Georg. Truth and Method. Second, Re. London and Newyork: Continuum Publishing Group, 2006. 
Haleem, M. A.S.Abdel. "The Role of Context in Interpreting and Translating the Qur'an." Journal of Qur'anic Studies 20, no. 1 (2018): 47-66. https://doi.org/10.3366/jqs.2018.0320.

Hammer, Juliane. "Identity, Authority, and Activism: American Muslim Women Approach the Qur'an.” The Muslim World 98, no. 4 (2008): 443-64.

Hidayah, Ulil. "Kontroversi Mushaf Utsmani." ULUL ALBAB Jurnal Studi Islam 15, no. 1 (2014): 44-56. https://doi.org/10.18860/ua.v14i3.2661.

Hitti, Philip K. History of the Arabs. Macmillan International Higher Education, 2002.

History of The Arabs. Jakarta Selatan: Zaman, 2018.

Hourani, Albert. A History of the Arab Peoples. Updated ed. Faber \& Faber, 2013. https://doi.org/10.1017/cbo9780511570780.005.

Jeffery, Arthur. "Materials for the History of the Text of the Qur'an." Leiden: Brill, 1937.

Jessica Brown. Fallibilism: Evidence and Knowledge. New York: Oxford University Press, 2018.

Knowlton, Brian. "Muslim Women Gain Higher Profile in US,” 2010.

Mattson, Ingrid. "Can a Woman Be an Imam? Debating Form and Function in Muslim Women's Leadership." The Columbia Sourcebook of Muslims in the United

States, 2005 , 252-63.

http://thewomenofislam.tripod.com/womenimams.pdf. - "How to Read The Quran." In The Study Quran: A New Translation and Commentary, edited by Seyyed Hossein Nasr, Caner K. Dagli, Maria Massi Dakake, and Joseph E. B. Lumbard. New York: HarperOne, 2015.

. The Story of The Qur'an: Its History and Place in Muslim Life. John Wiley \& Sons, 2013. https://doi.org/10.5860/choice.46-0829.

- Ulumul Quran Zaman Kita: Pengantar Untuk Memahami Konteks, Kisah, Dan Sejarah Al-Quran. Jakarta: Zaman, 2013.

."Women, Islam and Mosques." Encyclopedia of Women and Religion in North America 615, no. 618 (2006).

Mehr, Husayn 'Alawl. An Introduction to the History of Tafslr and Commentators of the Qur'an, Translator: Hamid Hussein Waqar. Qum: Al-Mustafa International Publication and Translation Center, 2012.

Muzhiat, Aris. "Historiografi Arab Pra Islam." Tsaqôfah: Jurnal Agama Dan Budaya 17, no. 2 (2019): 129-36.

Nasir, Muhammad. "Kriteria Keshahihan Hadis Perspektif Syiah.” Jurnal Farabi 
11, no. 2 (2014): 135-53.

Nasr, Seyyed Hossein, Caner K. Dagli, Maria Massi Dakake, Joseph E. B. Lumbard, and Mohammed Rustom. The Study Quran: A New Translation with Notes and Commentary. New York: HarperCollins Publishers, 2015.

Nasution, Harun. Teologi Islam. Jakarta: UI-Press, 2015.

Pink, Johanna. 'Literal Meaning'or 'Correct 'aqīda'? The Reflection of Theological Controversy in Indonesian Qur'an Translations." Journal of Qur'anic Studies 17, no. 3 (2015): 100-120. https://doi.org/10.3366/jqs.2015.0213.

. Muslim Qur'anic Interpretation Today: Media, Genealogies and Interpretive Communities. London: Advent Publishing Services, 2019.

. "Tradition, Authority and Innovation in Contemporary Sunnī Tafsīr: Towards a Typology of Qur'an Commentaries from the Arab World, Indonesia and Turkey." Journal of Qur'anic Studies 12, no. 2010 (2010): 56-82. https://doi.org/10.3366/e1465359110000963.

“Quran Surat Al-Baqarah Ayat 158,” 2020. https://tafsirweb.com/630-quransurat-al-baqarah-ayat-158.html.

"Quran Surat At-Taubah Ayat 34," 2020. https://tafsirweb.com/3050-quransurat-at-taubah-ayat-34.html.

Ramdane, Tahraoui, and Merah Souad. "Towards a New Approach in the Teaching of the Holy Qur'an." International Journal of Humanities and Social Science 7, no. 10 (2017): 143-52.

Reynolds, Gabriel Said. New Perspectives on the Qur'ann: The Qur'an in Its Historical Context 2. New York: Routledge, 2011.

Rippin, Andrew. Approaches to the History of the Interpretation of the Qur'an. Edited by Andrew Rippin. Oxford: Clarendon Press, 1988. https://doi.org/10.2307/1596080.

Saeed, Abdullah. Interpreting the Qur'an: Towards a Contemporary Approach. New York: Taylor \& Francis e-Library, 2006.

Islamic Thought: An Introduction. New York: Taylor \& Francis e-Library, 2006. https://doi.org/10.4324/9780203088685.

. The Qur'an: An Introduction. The Qur'an. New York: Taylor \& Francis eLibrary, 2008. https://doi.org/10.4324/9780203938454-12.

Vessey, David. "Gadamer and the Fusion of Horizons." International Journal of Philosophical Studies 17, no. 4 (2009): 531-42. 
98 | AL QUDS : Jurnal Studi Alquran dan Hadis vol. 5, no 1, 2021

https://doi.org/10.1080/09672550903164459. 